\title{
Evidence for conservation and sustainable use in a fragment of the Atlantic forest in southeastern Brazil by a traditional human group
}

\author{
Alexandre Gabriel Christo ${ }^{1,2}$, Rejan R Guedes-Bruni ${ }^{1}$, Felipe de Araújo Pinto Sobrinho ${ }^{1}$, Ary Gomes da Silva ${ }^{3 *}$
} and Ariane Luna Peixoto ${ }^{1}$

\begin{abstract}
The use of forest resources by a rural community adjacent to a Biological Reserve was examined using quantitative methods based on the consensus of six local specialists. Plants with trunk diameters at $1.3 \mathrm{~m}$ above soil level $(\mathrm{DBH}) \geq 5 \mathrm{~cm}$ were sampled in 0.5 ha of forest and their use-value (UV) were calculated and associated with their structural descriptors. A total of 129 species were identified, and 69 of them having known uses. The species with largest UV were: Xylopia sericea, Lecythis lanceolata and Guarea macrophylla. The results demonstrated that neither the degree of recognition of taxa by the local specialists nor their use-versatility depended on their abundance in nature. The results corroborate the hypothesis that richness of a plant family is a predictive character of its cultural importance and the community recognizes the value of conserving the forest remnants.
\end{abstract}

Keywords: Ethnobotany, Atlantic forest, Rural community, Use-value, Forest resource, Conservation

\section{Introduction}

Conservation of biological diversity represents one of the greatest current challenges for the mankind, due to the high degree of anthropogenic disturbance of all natural ecosystems al over the world (Lawrence 2010).

In Brazil, the land occupation, the degradation of natural landscape and the social aspects related to this context, has in the Amazonian region the greatest visibility both nationally and internationally, due to its geographic dimension, biological diversity and challenges of various origins (Mittermeier et al. 2005). Considering the megadiversity in the country (Gross et al. 2005), this forest is only a part of a bigger problem. The severe process of anthropization and subsequently suppression of vegetation areas had drastically reduced the limits of important Brazilian biomes (Castelletti et al. 2003), but no suppression was so severe such as the one that happened to the Atlantic Forest, limiting its remains to no more than 6\% of its original area (Fundação SOS Mata Atlântica 2009).

\footnotetext{
* Correspondence: arygomes@uvv.br

${ }^{3}$ Universidade Vila Velha-ES (UW), Rua Comissário José Dantas de Melo, 21, CEP: 29.102-770, Vila Velha, ES, Brazil

Full list of author information is available at the end of the article
}

The Atlantic Forest, due to the fact that it encompasses the geographic region where the first Brazilian cities were established - and nowadays, about $60 \%$ of the Brazilian population (Fundação SOS Mata Atlântica 2009) - was interconnected to the different economic cycles in the country, from the exploration of pau-brasil (Caesalpinia echinata Lam.), at the time the country was discovered, up to the incentive for the development of technology to produce bio fuel in the 70's (GuedesBruni et al. 2000). The agriculture fostered since the period of colonial Brazil (XVI - XVII centuries), allied to the mining activity in the southern country, had already damaged the forest landscape to a huge extent (Dean 1996), and endangered many plant and fauna species. Hence, the scientific studies concentrate predominantly in protected areas, reminiscent of a forest which was once pungent along the Brazilian Atlantic coast.

Ethnobotanical studies directed towards examining the relationships between humans and the forest as well as the natural populations of plant species and the impacts caused by use and management by human populations have been undertaken by numerous authors (PiñedoVásquez et al. 1990, Phillips and Gentry 1993a, b, Phillips et al. 1994, Chazdon and Coe 1999, Calderon 
et al. 2000, Galeano 2000, Aguilar and Condit 2001, Torre-Cuadros and Islebe 2003), but they are still incipient for a megadiverse country such as Brazil (Prance et al. 1987, Cunha and Albuquerque 2006, Soler-Alarcón and Peixoto 2008), and contain valuable information that can assist the management of useful species and the in situ conservation of threatened species.

Various studies have shown local knowledge to be extremely important in environmental diagnoses, especially in terms of its historical comprehension and long term observations (Donovan and Puri 2004, Cundill et al. 2005, Chalmers and Fabricius 2007). The knowledge retained by human populations living near remnant forests, especially those near conservation areas, can help indicate options for sustainable use and in situ conservation of valuable resources based on the history of that community and knowledge that it transmits orally from generation to generation (Albuquerque 1999).

This knowledge, as well as the Atlantic Forest itself, is threatened with extinction with the death or loss of memory of the oldest citizens, and by the disinterest of the younger community members who are now living in a globalized world with its emphasis on urban values (Christo et al. 2006). Ethnobotanical studies are important for strengthening the cultural identity of rural communities while at the same time strengthening concepts and scientific methodologies that synergistically influence the use and conservation of natural systems as demanded by public environmental policies (Albuquerque et al. 2009).

The present study sought to: (1) evaluate the use and importance of the arboreal species in an Atlantic Forest fragment as indicated by local specialists of a rural community near the Poço das Antas Biological reserve, in the municipality of Silva Jardim, Rio of Janeiro, Brazil, and (2) identify associations between the importance of these resources and their community structural absolute descriptors, such as dominance, density, and frequency.

\section{Study area}

The Gleba Aldeia Velha rural community (2230'20"S and $\left.42^{\circ} 16^{\prime} 30^{\prime \prime} \mathrm{W}\right)$ is in the municipality of Silva Jardim, on the central coast of Rio of Janeiro State, about $120 \mathrm{~km}$ distant from the state capital, and neighboring the Poço das Antas Biological Reserve where the predominant vegetation is Dense Ombrophilous lowland Atlantic Forest (Veloso et al. 1991), in different states of maturity (Lima et al. 2006).

Some of the inhabitants of the study community formerly lived in what is now part of the Reserve and were resettled along its borders after its creation at the end of the 1970's. Gleba Aldeia Velha is composed of approximately 60 families whose economic activities are based on small-scale agriculture, principally planting manioc (Manihot esculenta Crantz) and corn (Zea mays L.), as well as on animal husbandry, raising cattle for milk and meat (Christo et al. 2006). Occasionally, some individuals take a part in activities developed by NGOs, universities and research institutions in Reserve.

\section{Methods}

Field work was carried out between March 2007 and March 2008, when we interviewed six local specialists (men that retain specialized knowledge concerning the local native arboreal species) using questionnaires during semi-structured interviews (Alexiades and Sheldon 1996) focusing on their personal life histories and their relationships with, and use of, forest resources. Local specialists were 38 up to 72 year-old and they were harvesters in their majority, but sometime in the past, some of them had also worked in that area as loggers. Their instruction level was never higher than the fundamental education.

The informants were not randomly selected, as seen in Phillips and Gentry (1993a) but were chosen on the basis of indications from the community itself, taking into account their significant knowledge about the forest elements (Christo et al. 2006). A second semi-structured interview was later held with the same local specialists to obtain information about the use (use-categories and the plant parts utilized) of the plant species harvested and the localities where they were collected.

In order to identify possible associations between species use and their natural abundance and diversity, 20 sample plots $(10 \times 25 \mathrm{~m})$, totaling 0.5 ha, were laid out, and all individuals with $\mathrm{DBH} \geq 5 \mathrm{~cm}$ were recorded and, three branches of each species were collected to make vouchers that were deposited in the colletion of the Herbarium Barbosa Rodrigues, at the Rio de Janeiro Botanical Garden.Forest structural parameters and the analysis are found in Christo et al. (2009). The nomenclatural system adopted for plant families and species scientific names was the one of the Angiosperm Phylogeny Group - APGIII (Bremer et al. 2009). Additional ethnobotanical data was collected by way of a third series of interviews with the local specialist during walks in the sample plots. During these walks the men identified the plants by name and indicated their uses and the plant parts used. These ethnobotanical data were used to calculate the UV of each species $s$ for each informant $i\left(\mathrm{UV}_{\mathrm{is}}\right)$ as well as the use-value of each species $s\left(U_{\mathrm{s}}\right)$, as proposed by Phillips and Gentry (1993a).

To calculate the use-value of the plant families, the methodology suggested by Phillips and Gentry (1993a) and modified by Galeano (2000) was adopted, in which the UV for each species $\mathrm{s}$ belonging to family $F$ are summed, without dividing by the total number of useful species per family. The uses identified by the local specialists were grouped into nine categories: foods, medicinal, construction, firewood, ornamental, ritualistic, 
technological (comprises crafts made with wood, such as toys, tool handles, furniture, and housewares) and toxic. These same categories have been used in other ethnobotanical studies that have analyzed arboreal vegetation (Prance et al. 1987, Piñedo-Vásquez et al. 1990, Phillips and Gentry 1993a, b, Phillips et al. 1994, Galeano 2000, Torre-Cuadros and Islebe 2003).

Plants included within the category "firewood" are normally grouped within the category "technology" (Phillips and Gentry 1993a), but here we considered them as distinct categories, in light of the importance that firewood use has for the local community - as identified by Christo et al. (2006), and corroborating with the categories adopted by Galeano (2000) and Cunha and Albuquerque (2006).

Linear regression analysis was used to identify the association between the importance of each species for the local specialists in relation to its availability, comparing the use-value of each species with the structural descriptors of density and dominance, and with the richness of the plant families.

The identification of the botanical families that were sub-utilized or highly used, in relation to their species richness, was performed by processing the residuals obtained by the linear regression calculated with an independent variable (richness) and a dependent variable (the use-value of the family), following Phillips and Gentry (1993a) and Galeano (2000). Assuming $\alpha=0.05$, the families that have residual values either greater or lesser than 1.96 were identified as families that are either super- or sub-utilized respectively in relation to the richness values obtained in the structural analysis of the forest (Phillips and Gentry 1993a).

Samples of all botanical material were collected with the indication of the informant and identified using analytical keys, taxonomic reviews, comparisons with herbarium collections and with the help of taxonomists. The classification system adopted follows APG III (2009). All voucher material was deposited in the herbarium of the Rio de Janeiro Botanical Garden (RB). See Christo et al. (2009) for A. G. Christo's collection numbers.

\section{Results and discussion}

In the fragment sampled, a total of 734 individual plants were recorded, belonging to 129 species in 41 families (Table 1). Concerning the ethnobotanical results, nearly $53.49 \%$ of the species $(69)$ and $78.20 \%$ (574) of the individuals were recognized by the local specialists as having some kind of utility.

The state of forest provides much information about past economic activities. For instance in spite of the impacts produced by lumber industry, it is, the principal reason for the existing traditional knowledge even four decades after that activity had ceased. There is an intricate web of relationships in natural areas that keep in contact people and situations like: rural workers; lumber industry activities; scientists; environmentalists; NGOs; local politicians; forest resources scarcity; trustworthy economic alternatives to rural workers; and conflicting interests among groups.

Studies in Amazonian forest areas have shown the highest use-values, from 60 up to $98 \%$ of species (Piñedo-Vásquez et al. 1990, Phillips et al. 1994, Galeano 2000, Soler-Alarcón and Peixoto 2008). The only available data for the Atlantic Rain Forest is 100\% (Cunha and Albuquerque 2006), where all of 42 shrub and tree species were used by local human communities.

A total of 30 uses were registered for the species that were grouped in eight categories, and among them, construction (11 indications), and technology (10) comprised most of the indications. Most of the species demonstrated low levels of use-versatility, ranging from one up to four uses.

The traditional specialists studied recognized the importance of conserving the remnant forests as a way of protecting the resources they use, thus presenting the possibility of recruiting them as front-line agents for the conservation and management of the Atlantic Forest, a forest that is currently too reduced of its original area in Rio of Janeiro State.

Cunha and Albuquerque (2006) reported finding six up to ten uses for 15 species (among the 42 reported as being useful), while Soler-Alarcón and Peixoto (2008) reported that $43 \%$ of the 185 species inventoried in an area of Amazonian Forest, ranging from six up to ten uses.

The construction category had the largest number of useful species cited (40 spp.), followed by firewood (24), and then technology (20) (Figure 1). When considering the total numbers of citations, construction had 51.77\% of the use-indications of the local specialists, while $22.79 \%$ were indications for technological purposes, and $18.56 \%$ for firewood.

The background of the traditional specialists had a very strong influence on the results of the research reported here, as these men were predominantly exwood harvesters and most of their knowledge about the forest was focused on tree species used as timber, as could be observed during the fieldwork. There was an intense activity in traditional economy as a consequence of the lumber industry in the 1940's that were spread throughout the central coastal area of Rio of Janeiro. Their former occupations explain their accuracy in recognizing fully $78.20 \%$ of the arboreal individuals sampled and $53.49 \%$ of the species encountered.

Most of the species had low UV and only a few had a high number of uses according to the traditional specialists, indicating that each species has essentially only one typical use. Considering the distribution of the number of 
Table 1 Use-value and structural descriptors of the arboreal species considered useful by local specialists in rural community, Brazil, presented in decreasing absolute dominance order (Ab.Dom)

\begin{tabular}{|c|c|c|c|c|}
\hline Species & Ab.Dom & Ab.Freq. & Ab.Dens & UV \\
\hline Piptocarpha macropoda (DC.) Baker & 1.1184 & 24.0 & 35.0 & 1.50 \\
\hline Tapirira guianensis Aubl. & 1.1021 & 24.0 & 45.0 & 2.17 \\
\hline Aparisthmium cordatum Baill. & 1.0587 & 102.0 & 75.0 & 1.20 \\
\hline Guapira opposita (Vell.) Reitz & 1.0543 & 86.0 & 80.0 & 1.00 \\
\hline Xylopia sericea A. St.-Hil. & 0.9801 & 34.0 & 55.0 & 3.40 \\
\hline Albizia polycephala (Benth.) Killip & 0.8578 & 32.0 & 25.0 & 2.17 \\
\hline Malpighiaceae 1 & 0.8163 & 34.0 & 35.0 & 1.40 \\
\hline Guatteria xylopioides R.E.Fr. & 0.7319 & 38.0 & 50.0 & 1.80 \\
\hline Malouetia arborea (Vell.) Miers & 0.6146 & 6.0 & 15.0 & 1.80 \\
\hline Cabralea canjerana (Vell.) Mart. & 0.5618 & 40.0 & 65.0 & 2.40 \\
\hline Hieronyma oblonga (Tul.) Müll. Arg. & 0.5278 & 22.0 & 35.0 & 1.83 \\
\hline Pogonophora schomburgkiana Miers & 0.5096 & 22.0 & 15.0 & 1.67 \\
\hline Siparuna brasiliensis (Spreng.) A. DC. & 0.4940 & 44.0 & 55.0 & 1.20 \\
\hline Lacistema pubescens Mart. & 0.4860 & 68.0 & 60.0 & 1.00 \\
\hline Annona cacans Warm. & 0.4635 & 4.0 & 10.0 & 0 \\
\hline Nectandra oppositifolia Nees \& Mart. & 0.4608 & 22.0 & 30.0 & 1.67 \\
\hline Virola oleifera (Schott) A.C. Sm. & 0.4349 & 14.0 & 20.0 & 1.75 \\
\hline Alchornea triplinervia (Spreng.) Müll. Arg. & 0.4245 & 6.0 & 10.0 & 2.60 \\
\hline Jacaranda micrantha Cham. & 0.3940 & 10.0 & 20.0 & 2.60 \\
\hline Simarouba amara Aubl. & 0.3844 & 10.0 & 25.0 & 1.50 \\
\hline Myrcia anceps O. Berg & 0.3752 & 56.0 & 45.0 & 1.17 \\
\hline Cupania racemosa (Vell.) Radlk. & 0.3171 & 16.0 & 35.0 & 1.20 \\
\hline Rinorea guianensis Aubl. & 0.3144 & 30.0 & 35.0 & 1.60 \\
\hline Ocotea divaricata (Nees) Mez & 0.2905 & 36.0 & 55.0 & 1.67 \\
\hline Asteraceae 1 & 0.2899 & 6.0 & 15.0 & 1.00 \\
\hline Aniba firmula (Nees \& Mart.) Mez & 0.2739 & 32.0 & 45.0 & 2.50 \\
\hline Chrysophyllum lucentifolium Cronquist & 0.2568 & 2.0 & 5.0 & 0 \\
\hline Bathysa mendoncaei K. Schum. & 0.2440 & 46.0 & 45.0 & 1.00 \\
\hline Ocotea schottii (Meisn.) Mez & 0.2214 & 10.0 & 15.0 & 1.00 \\
\hline Miconia cinnamomifolia (DC.) Naudin & 0.1954 & 8.0 & 15.0 & 1.60 \\
\hline Eugenia oblata Roxb. & 0.1925 & 8.0 & 15.0 & 1.80 \\
\hline Rollinia dolabripetala (Raddi) R.E. Fr. & 0.1857 & 8.0 & 15.0 & 0 \\
\hline Cupania furfuracea Radlk. & 0.1776 & 26.0 & 35.0 & 1.25 \\
\hline Astrocaryum aculeatissimum (Schott) Burret & 0.1618 & 20.0 & 30.0 & 1.00 \\
\hline Vitex polygama Cham. & 0.1585 & 2.0 & 5.0 & 0 \\
\hline Cecropia hololeuca Miq. & 0.1562 & 12.0 & 15.0 & 1.60 \\
\hline Siparuna reginae (Tul.) A.DC. & 0.1552 & 14.0 & 25.0 & 0 \\
\hline Phyllostemonodaphne geminiflora Kosterm. & 0.1484 & 4.0 & 10.0 & 1.67 \\
\hline Calyptranthes lucida Mart. ex DC. & 0.1415 & 18.0 & 30.0 & 0 \\
\hline Pseudopiptadenia contorta (DC.) G.P. Lewis \& M.P. Lima & 0.1412 & 8.0 & 15.0 & 1.50 \\
\hline Roupala sculpta Sleumer & 0.1336 & 10.0 & 15.0 & 1.20 \\
\hline Ormosia cf. minor Vogel & 0.1332 & 8.0 & 20.0 & 1.00 \\
\hline Marlierea obscura O. Berg & 0.1318 & 2.0 & 5.0 & 0 \\
\hline Hirtella angustifolia Schott ex Spreng. & 0.1278 & 4.0 & 5.0 & 2.25 \\
\hline Himatanthus bracteatus (A. DC.) Woodson & 0.1268 & 16.0 & 25.0 & 1.00 \\
\hline Ocotea diospyrifolia (Meisn.) Mez & 0.1231 & 10.0 & 20.0 & 1.20 \\
\hline
\end{tabular}


Table 1 Use-value and structural descriptors of the arboreal species considered useful by local specialists in rural community, Brazil, presented in decreasing absolute dominance order (Ab.Dom) (Continued)

\begin{tabular}{|c|c|c|c|c|}
\hline Psychotria vellosiana Benth. & 0.1226 & 30.0 & 40.0 & 0 \\
\hline Tibouchina arborea Cogn. & 0.1129 & 6.0 & 15.0 & 1.83 \\
\hline Ecclinusa ramiflora Mart. & 0.1121 & 6.0 & 10.0 & 2.20 \\
\hline Casearia arborea (Rich.) Urb. & 0.1116 & 32.0 & 50.0 & 0 \\
\hline Licaria sp. & 0.1063 & 8.0 & 15.0 & 2.80 \\
\hline Helicostylis tomentosa (Poepp. \& Endl.) Rusby & 0.0989 & 20.0 & 40.0 & 0 \\
\hline Guarea guidonia (L.) Sleumer & 0.0913 & 6.0 & 5.0 & 2.50 \\
\hline Miconia lepidota Schrank \& Mart. ex DC. & 0.0903 & 8.0 & 15.0 & 1.20 \\
\hline Pera glabrata (Schott) Poepp. ex Baill. & 0.0878 & 6.0 & 15.0 & 0 \\
\hline Protium heptaphyllum (Aubl.) Marchand & 0.0860 & 12.0 & 25.0 & 0 \\
\hline Jacaranda puberula Cham. & 0.0839 & 14.0 & 25.0 & 1.33 \\
\hline Miconia sp. & 0.0794 & 18.0 & 20.0 & 1.20 \\
\hline Stryphnodendron polyphyllum Mart. & 0.0792 & 8.0 & 20.0 & 2.00 \\
\hline Copaifera langsdorffii Desf. & 0.0758 & 2.0 & 5.0 & 1.67 \\
\hline Ocotea glaziovii Mez & 0.0731 & 4.0 & 10.0 & 1.17 \\
\hline Ocotea sp.1 & 0.0673 & 8.0 & 20.0 & 1.20 \\
\hline Psychotria carthagenensis Jacq. & 0.0628 & 8.0 & 20.0 & 0 \\
\hline Trichilia martiana C. DC. & 0.0577 & 2.0 & 5.0 & 0 \\
\hline Leretia cordata Vell. & 0.0576 & 4.0 & 10.0 & 0 \\
\hline Erythroxylum citrifolium A. St.-Hil. & 0.0557 & 14.0 & 25.0 & 0 \\
\hline Ocotea daphnifolia (Meisn.) Mez & 0.0540 & 4.0 & 5.0 & 0 \\
\hline Cybistax antisyphilitica (Mart.) Mart. & 0.0534 & 4.0 & 5.0 & 0 \\
\hline Ocotea laxa (Nees) Mez & 0.0473 & 6.0 & 5.0 & 0 \\
\hline Mollinedia oligantha Perkins & 0.0447 & 4.0 & 10.0 & 0 \\
\hline Strycnos sp. & 0.0422 & 2.0 & 5.0 & 1.00 \\
\hline Polyandrococos caudescens (Mart.) Barb. Rodr. & 0.0367 & 2.0 & 5.0 & 1.00 \\
\hline Ocotea brachybotrya (Meisn.) Mez & 0.0365 & 2.0 & 5.0 & 0 \\
\hline Pera heteranthera (Schrank) I.M. Johnst. & 0.0342 & 10.0 & 20.0 & 0 \\
\hline Copaifera lucens Dwyer & 0.0337 & 2.0 & 5.0 & 1.33 \\
\hline Mabea fistulifera Mart. & 0.0302 & 4.0 & 10.0 & 0 \\
\hline Maytenus samydaeformis Reissek & 0.0300 & 8.0 & 20.0 & 0 \\
\hline Leretia cordata Vell. & 0.0299 & 4.0 & 10.0 & 0 \\
\hline Persea sp. & 0.0294 & 2.0 & 5.0 & 0 \\
\hline Licania octandra (Hoffmanns. ex Roem. \& Schult.) Kuntze & 0.0276 & 6.0 & 15.0 & 1.20 \\
\hline Urbanodendron cf. bahiense (Meisn.) Rohwer & 0.0275 & 4.0 & 10.0 & 0 \\
\hline Erythroxylum cuspidifolium Mart. & 0.0270 & 8.0 & 15.0 & 0 \\
\hline Eugenia sp.2 & 0.0268 & 2.0 & 5.0 & 0 \\
\hline Malpighiaceae 2 & 0.0265 & 2.0 & 5.0 & 0 \\
\hline Solanum inaequale Vell. & 0.0253 & 2.0 & 5.0 & 0 \\
\hline Kielmeyera excelsa Cambess. & 0.0241 & 4.0 & 10.0 & 0 \\
\hline Eugenia speciosa Cambess. & 0.0226 & 4.0 & 10.0 & 0 \\
\hline Siparuna guianensis Aubl. & 0.0215 & 6.0 & 15.0 & 1.20 \\
\hline Swartzia oblata R.S.Cowan & 0.0212 & 2.0 & 5.0 & 0 \\
\hline Lecythis lanceolata Poir. & 0.0201 & 2.0 & 5.0 & 0 \\
\hline Alchornea sidifolia Müll. Arg. & 0.0200 & 4.0 & 5.0 & 0 \\
\hline Senegalia sp. & 0.0199 & 4.0 & 10.0 & 0 \\
\hline Calyptranthes brasiliensis Spreng. & 0.0198 & 4.0 & 5.0 & 1.17 \\
\hline
\end{tabular}


Table 1 Use-value and structural descriptors of the arboreal species considered useful by local specialists in rural community, Brazil, presented in decreasing absolute dominance order (Ab.Dom) (Continued)

\begin{tabular}{|c|c|c|c|c|}
\hline Euterpe edulis Mart. & 0.0190 & 6.0 & 15.0 & 1.33 \\
\hline Pseudobombax grandiflorum (Cav.) A. Robyns & 0.0175 & 2.0 & 5.0 & 0 \\
\hline Calophyllum brasiliense Cambess. & 0.0158 & 2.0 & 5.0 & 2.40 \\
\hline Lecythis lanceolata Poir. & 0.0156 & 4.0 & 10.0 & 1.20 \\
\hline Myrsine coriacea (Sw.) R. Br. ex Roem. \& Schult. & 0.0153 & 2.0 & 5.0 & 1.00 \\
\hline Guarea kunthiana A. Juss. & 0.0151 & 4.0 & 5.0 & 2.00 \\
\hline Myrcia splendens (Sw.) DC. & 0.0148 & 2.0 & 5.0 & 0 \\
\hline Eugenia sp.3 & 0.0143 & 2.0 & 5.0 & 0 \\
\hline Eugenia sp.1 & 0.0140 & 2.0 & 5.0 & 1.50 \\
\hline Cupania sp. & 0.0134 & 2.0 & 5.0 & 0 \\
\hline Handroanthus heptaphyllus Mattos & 0.0132 & 4.0 & 10.0 & 0 \\
\hline Calyptranthes cf. lanceolata O. Berg & 0.0129 & 2.0 & 5.0 & 0 \\
\hline Ocotea sp.2 & 0.0125 & 2.0 & 5.0 & 0 \\
\hline Licania octandra (Hoffmanns. ex Roem. \& Schult.) Kuntze & 0.0120 & 2.0 & 5.0 & 0 \\
\hline Trichilia casaretti C. DC. & 0.0116 & 2.0 & 5.0 & 0 \\
\hline Pouteria bangii (Rusby) T.D. Penn. & 0.0113 & 4.0 & 5.0 & 1.20 \\
\hline Cupania schizoneura Radlk. & 0.0108 & 2.0 & 5.0 & 1.20 \\
\hline Guarea macrophylla Vahl & 0.0107 & 4.0 & 10.0 & 2.67 \\
\hline Inga tenuis (Vell.) Mart. & 0.0106 & 2.0 & 5.0 & 1.00 \\
\hline Miconia prasina (Sw.) DC. & 0.0101 & 4.0 & 10.0 & 0 \\
\hline Pourouma guianensis Aubl. & 0.0096 & 4.0 & 10.0 & 0 \\
\hline Tabebuia sp.3 & 0.0089 & 2.0 & 5.0 & 0 \\
\hline Eugenia magnifica Spring & 0.0088 & 2.0 & 5.0 & 0 \\
\hline Myrcia sp.1 & 0.0086 & 2.0 & 5.0 & 0 \\
\hline Calyptranthes sp. & 0.0070 & 2.0 & 5.0 & 0 \\
\hline Machaerium brasiliense Vogel & 0.0069 & 2.0 & 5.0 & 0 \\
\hline Duguetia pohliana Mart. & 0.0064 & 2.0 & 5.0 & 0 \\
\hline Tachigalli pilgeriana (Harms) Oliveira-Filho & 0.0064 & 2.0 & 5.0 & 0 \\
\hline Cupania oblongifolia Mart. & 0.0061 & 2.0 & 5.0 & 1.33 \\
\hline Brosimum guianense (Aubl.) Huber & 0.0056 & 2.0 & 5.0 & 1.25 \\
\hline Gomidesia sp. & 0.0052 & 2.0 & 5.0 & 0 \\
\hline Cyathea corcovadensis (Raddi) Domin & 0.0049 & 2.0 & 5.0 & 0 \\
\hline Eugenia tinguyensis Cambess. & 0.0049 & 2.0 & 5.0 & 0 \\
\hline Myrtaceae 1 & 0.0046 & 2.0 & 5.0 & 0 \\
\hline Couepia venosa Prance & 0.0044 & 2.0 & 5.0 & 0 \\
\hline Simaba sp. & 0.0042 & 2.0 & 5.0 & 0 \\
\hline
\end{tabular}

$\mathrm{UV}=$ use-value, $\mathrm{Ab}$.Freq= absolute frequency, Ab.Dens.= absolute density.

use-citations per family in the various use-categories (Figure 2), Lauraceae stands out in terms of the absolute number of citations, although it demonstrates low versatility among the different use categories, with its component taxa being restricted to the categories of construction and technology. Fabaceae, with a slightly smaller number of citations than Lauraceae, is distributed among six distinct use-categories: medicinal, construction, firewood, ornamental, ritualistic, and technological. The third family in number of citations was Euphorbiaceae, being cited in three categories (construction, firewood, and technology).

Cunha and Albuquerque (2006) noted the importance of Fabaceae, Melastomataceae, Burseraceae, and Anacardiaceae in numbers of uses, the majority of which were related to construction and technology. In studies undertaken in two indigenous areas in the Amazonian Forest in Brazil, Prance et al. (1987) indicated the families Arecaceae, Apocynaceae, Clusiaceae, and Chrysobalanaceae 


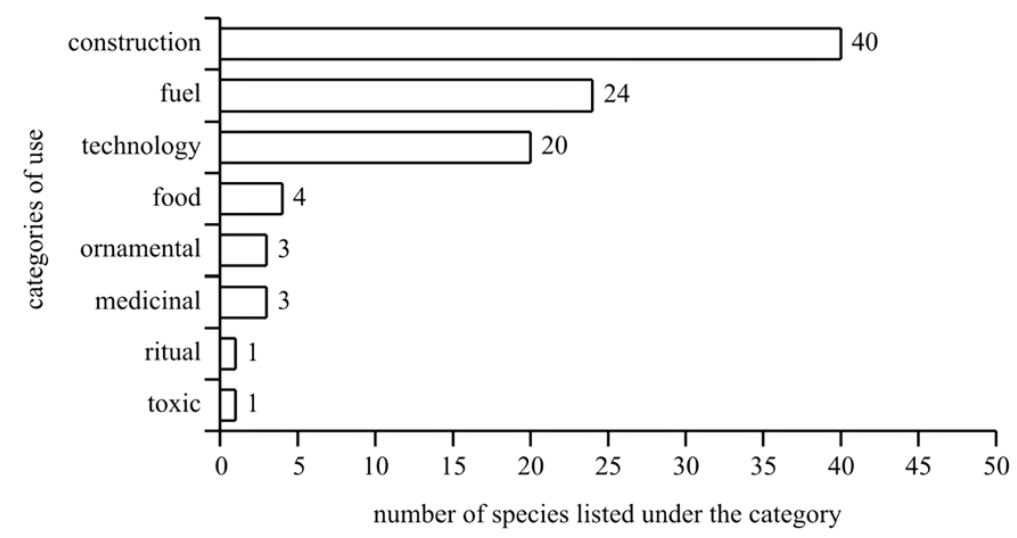

Figure 1 Distribution of the numbers of species in use-categories mentioned by traditional specialist on ethnobotanical survey in rural community, municipality of Silva Jardim, RJ, Brazil.

as being most important for the Ka'apor Amerindians; while for the Tembé indigenous tribe Arecaceae, Chrysobalanaceae, Annonaceae, and Lauraceae stood out. It is worth pointing out that the families Fabaceae, Lauraceae, Melastomataceae, and Arecaceae are widely distributed in the country, occurring in many different vegetation formations, and have significant roles in the characterization of those physiognomies.

The selective extraction of lumber for construction constitutes the most common use of forest products, and they are used in residences and in shelters for domestic animals. Among all of the species encountered, 58\% were used for this, and $70 \%$ of those species where used exclusively in this category. The families most indicated for construction use are Lauraceae, Fabaceae, Euphorbiaceae, Meliaceae, Melastomataceae, Annonaceae, Anacardiaceae, and Sapotaceae.

Firewood is the second largest use and included 24 species. The families most used are Sapindaceae and Euphorbiaceae, the latter having the greatest number of use-citations. Wood is directly used for cooking and for

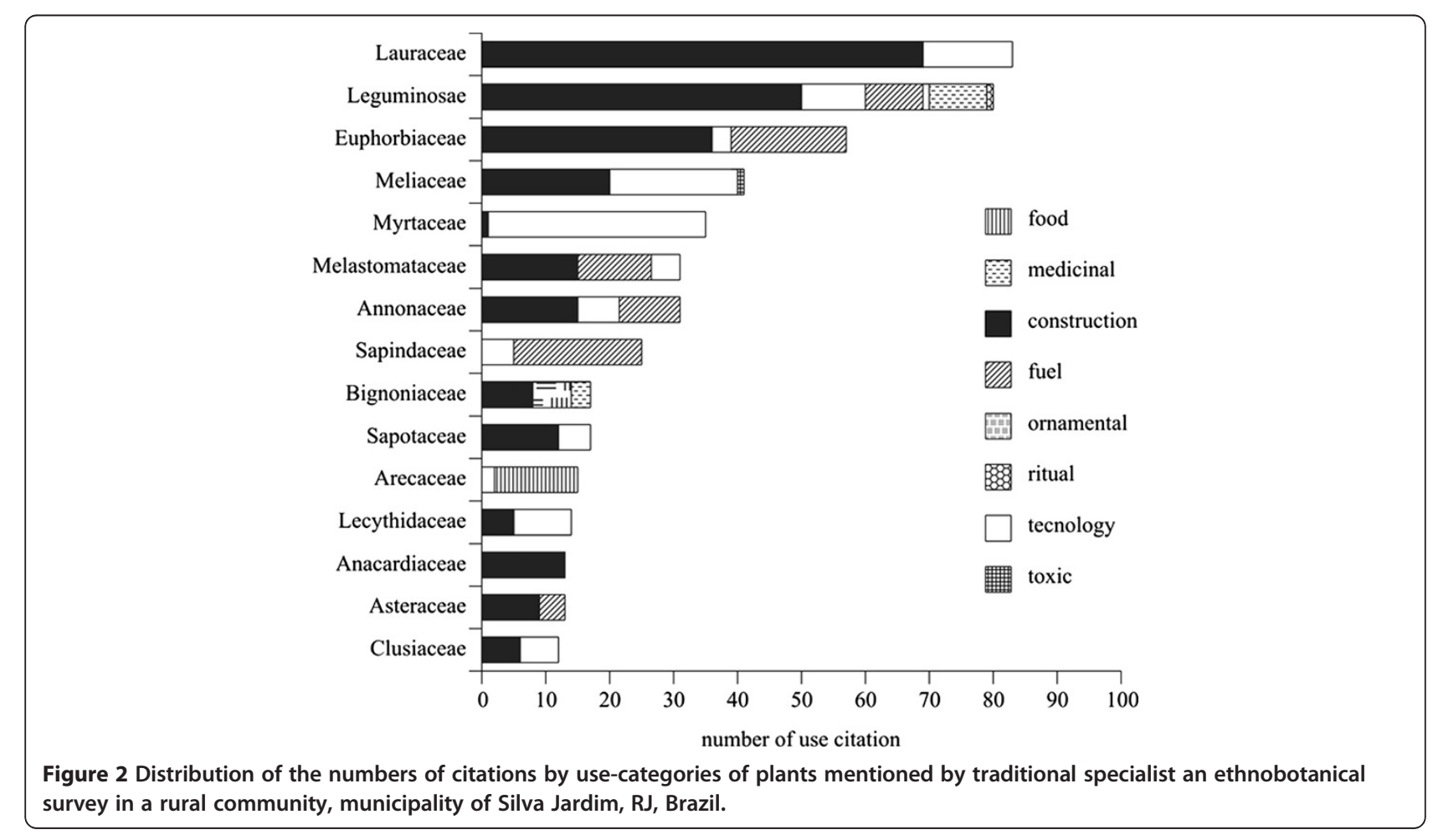


preparing manioc flour, as well as to produce charcoal. Some residences have their own charcoal-manufacturing kilns made of mud and called a charcoal hearth.

In the technology category, wood is used basically for making handles for tools as well as crates for transporting farm produce. According to some of the traditional specialists, the practice of making these wooden crates greatly reduced the number of certain plant species in the region due to excessive demand in the past for boxwood to supply an industry installed in the region.

The food uses of forest species were concentrated in Arecaceae - the source of palm-hearts. Within the fragment studied, three palm tree species are harvested for this purpose: Astrocaryum aculeatissimum, Euterpe edulis, and Polyandrococos caudescens. The search for Euterpe edulis, the most appreciated palm-heart, was responsible for the accentuated destruction of the forests of Rio of Janeiro, as this species was once very abundant along the
Atlantic coast, growing even on the mountainsides. Vestiges of cut palms were found in the sample plots.

Only three species were recognized as having medicinal properties: Jacaranda puberula was indicated for treating itching, using the leaf to prepare an infusion. Copaifera langsdorffii and C. lucens were indicated for treating afflictions of the digestive system, using the plant sap. The ornamental category had three species: Jacaranda micrantha, J. puberula, and Tibouchina arborea. The traditional specialists indicated that these plants were considered ornamental due to their large size and showy flowers. Two categories had only a single species: Guarea guidonia is considered toxic to cattle; and the seeds of Ormosia cf. minor are used for adornment in Afro-Brazilian cult rituals.

The data demonstrated that the species in the fragment with high UV appeared to have low relative density (RD) - suggesting that the species with the greatest

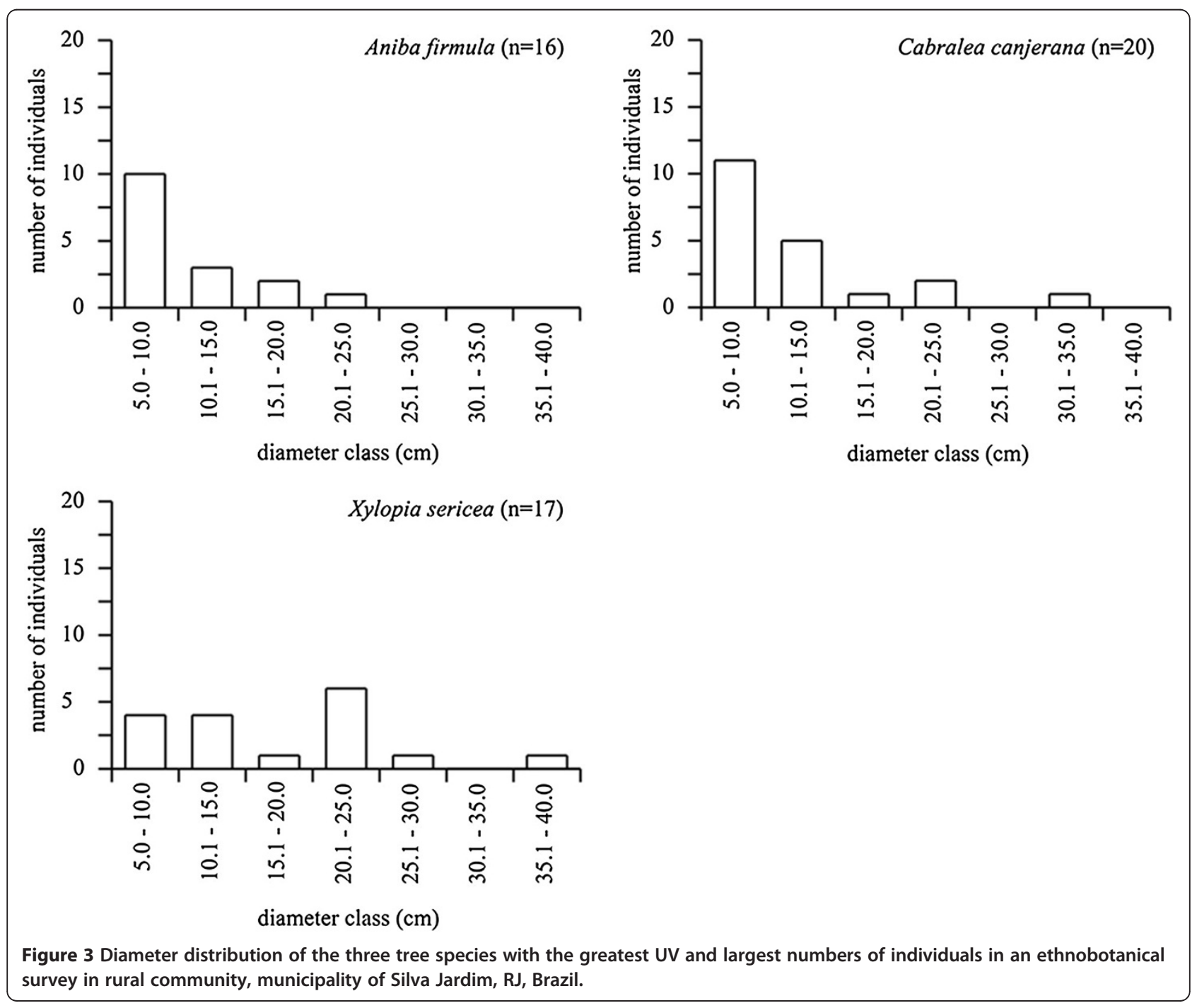


versatility had reduced populations - this association was not in fact found to be significant (UV $=1.59$ $2.57 * \mathrm{RD} ; \mathrm{r}^{2}=0.004 ; \mathrm{F}=0.266 ; p>0.05$ ). Of the three species that stood out as having the highest UV: Xylopia sericea, Lecythis lanceolata, and Guarea macrophylla; the last two demonstrated very low RD in the study fragment ( 0.54 and 0.27 respectively).

A similar situation was noted in the association between high UV and high relative dominance (RDo). The results also were not significant ( $\mathrm{UV}=1.45+8.64 * \mathrm{RDo}$; $\left.\mathrm{r}^{2}=0.049 ; \mathrm{F}=3.447 ; p>0.05\right)$, although the species with the greatest UV was the species with the greatest RDo (4.54) - which may be related to the size of the population (17 individuals) and to their bulk.

In this forest fragment, at the species level, the usevalue was not dependent on either the species abundance or their dominance. It may be an indicative for conservation, because the low density or even rarity must not necessarily prevent a plant species to be taken for human use, what may endanger them. Some plant species of rare occurrence in Atlantic Rain Forest inventories, with a single individual per hectare, may represent more than $50 \%$ of the sampled taxa, which contributes to the high diversity indexes of these forests (Guedes-Bruni et al. 2009). This rarity pattern must be taken into account before drawing conclusions about the eventual results from the management by local people.

The analysis of diameter distributions of the three species with the highest UV and populations of greater than 15 individuals (Figure 3) demonstrated that Aniba firmula and Cabralea canjerana had inverted "J" distribution patterns, indicating typical demographic regeneration patterns. Xylopia sericea, on the other hand, did not demonstrate this pattern, suggesting problems during its regeneration process in a given stage of the community, or an alteration directly related to the taxon. In examining the structural descriptors of this species and associating them to ethnobotanical data, it could be seen that Xylopia sericea is heavily used for constructing roofs for local residences, and trees with stem diameters between 5 and $20 \mathrm{~cm}$ are preferentially harvested. This specific diameter selection results in reduced numbers of individuals in the first two diameter classes in the forest fragment studied. Those individuals not selectively harvested will grow and occupy the canopy layer at maturity, making up the tallest individuals in the fragment.

The association between the use-value of a given family and its richness (Figure 4) was significant and positive $\left(\mathrm{UV}_{\mathrm{f}}=1.02+0.66 * \mathrm{~N} . \mathrm{Spp} ; \mathrm{r}^{2}=0.723 ; F=70.542 ; p<0.0001\right)$. The best predictor of a species' usefulness is therefore

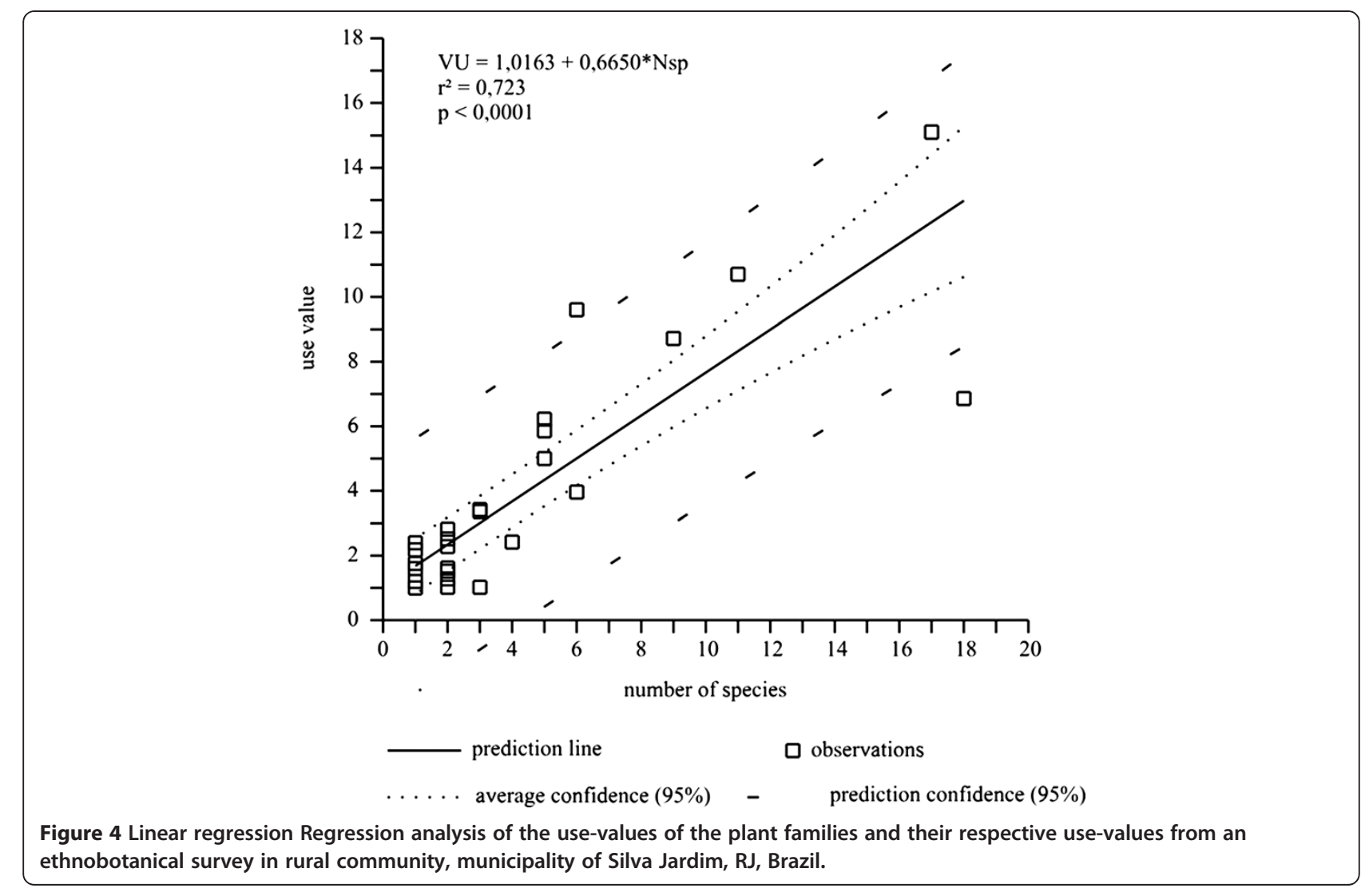




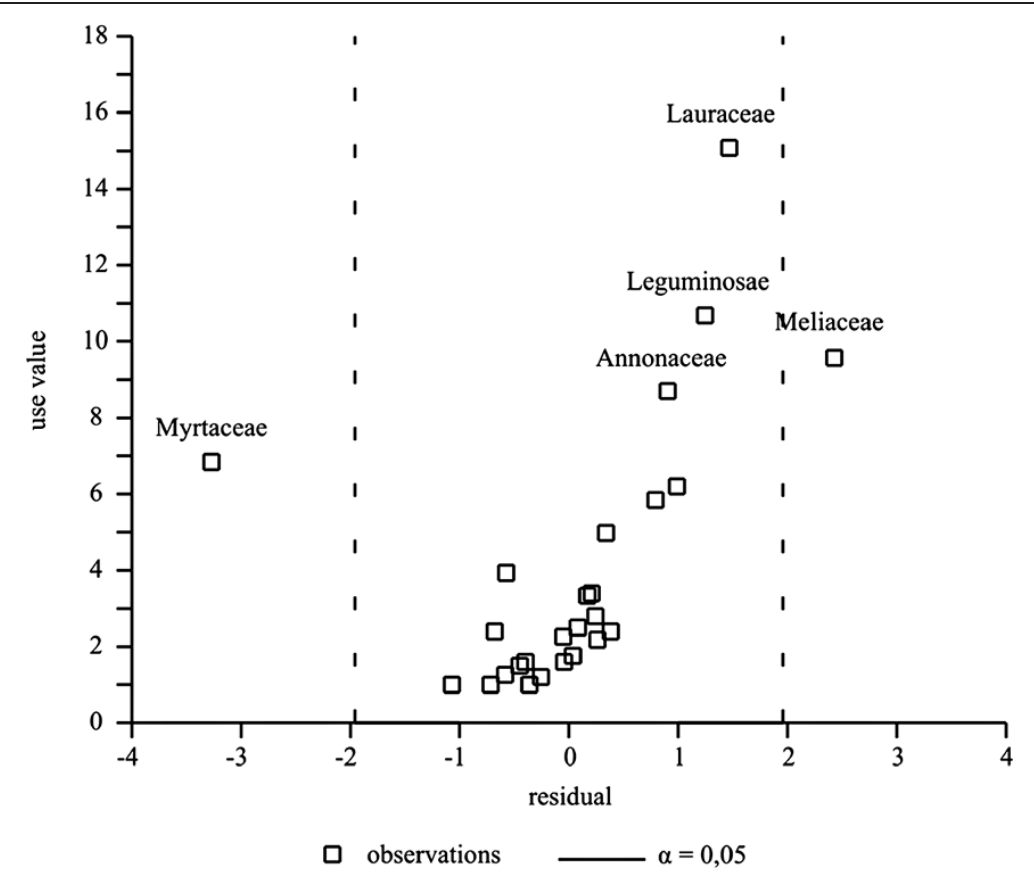

Figure 5 Analysis of the residual standard errors obtained by the linear regression between the use-values of the families and their respective use-values from an ethnobotanical survey in rural community, municipality of Silva Jardim, RJ, Brazil.

associated with family richness, corroborating the results reported by (Moerman 1996).

In the residual plots (Figure 5), the families are represented by observation points. Assuming $\alpha=0.05$, the family Myrtaceae is apparently under-used in light of its high species richness, considering the low use-values attributed to it by the traditional specialists. In spite of the fact that this family is recognized as having a large number of species in the Atlantic Forest, these plants were basically only used to make tool handles, as they have smooth trunks and their soft-textured wood is comfortable to grip. Additionally, the species sampled possess a shrubby habitus and thus less valued by the traditional specialists who are more interested in lumber species. Meliaceae, however, was over-used due to its low richness but high use-value. Six species of this family occurred in the area, all of them valued for producing wood used in house construction and for making furniture.

Larrère et al. (2003) observed that "Biodiversity is the result of the interaction of natural processes and human activities acting over long time scales. Human activities are not necessarily unfavorable to biological diversity. Conservation, in itself, is not restricted solely to nature but includes human culture". As such, traditional knowledge concerning the uses and populations sizes of forest species should be consulted when preparing proposals for management activities that intend to conserve plant resources and when developing sustainable alternatives to guarantee the permanence and well-being of those rural communities.
Interdisciplinary investigations that evaluate the structure of forest fragments together with the use of those resources by traditional rural communities can provide important information for future in situ conservation programs, while at the same time offering the prospect of sustainable management and use of natural products by those same communities.

\section{Conclusions}

The knowledge accumulated by local specialists during their work harvesting native trees had influenced their manner of seeing the forest, and even though they were assisting a scientific research project (and were aware of the importance of conserving the forest as a whole), these specialists consistently attributed greater value to arboreal species, especially those valued as lumber species. When considering the total number of use-citations to construction, technological, and firewood uses, the association between past experience as lumber extractors and theirs actual activities as rural workers is expressed.

The association between the importance of these resources and their structural descriptors were not observed. The plant resource selection is related to specific demand, regulated by different activities of the subsistence, as cooking, making handles for tools, building shelter for animals and home construction. Conservation actions to some species should be case to case, considering the species 
density, geographic occurrence, reproduction, and importance as a plant resource.

The way of use and the demand on the forest resource by traditional people should be taken into consideration in conservation programs, considering the immediate dependence of rural workers on forest resources to benefit their agricultural products (e.g. mandioc flour), as well as for their constructions. A survey about forest plant species conservation should be individually made for each useful species, also considering their distribution patterns in nature.

\section{Competing interests}

The authors declare that they have no competing interests.

\section{Authors' contibutions}

AGC, RRGB, ALP had planned and designed the theoretical and field research; AGC carried out the fieldwork; AGC, RRGB, FAPS, and ALP had made the taxonomic identification of plant families and species; AGC and AGS had run the statistical analysis; AGC, RRGB, AGS, and ALP draft the original manuscript; AGS revised the manuscript and was the responsable for corrections and final revision, as corresponding author. All authors read and approved the final manuscript.

\section{Authors' information}

Ariane Luna Peixoto ${ }^{d}$

${ }^{\mathrm{d} C N P q}$ fellow

\section{Acknowledgements}

The authors would like to thank Escola Nacional of Botânica Tropical (ENBT/ JBRJ); PETROBRAS for financing the "Mata Atlantica" Program (JBRJ); A. T. Oliveira, A. Pintor, and J. A. Dias for their help with the field work; the CAPES for the Masters grant to the first author; to CNPq for the researcher grant of Ariane L. Peixoto; to FUNADESP for the researcher grant of Ary G. Silva; to the Poço das Antas Biological Reserve / IBAMA for their logistical support; the taxonomists A. Quinet, H. C. de Lima, J. F. A. Baumgratz, and M. C. Souza; the owners of the Santa Helena Farm for allowing us free access to the study site; Professor Sir GT. Prance for comments and suggestion, and to the biologist Roy Funch for the English version.

\section{Author details \\ 'Jardim Botânico do Rio de Janeiro (JBRJ), Rua Pacheco Leão, 915, CEP 22.460-030, Rio de Janeiro, RJ, Brazil. ${ }^{2}$ Pontifícia Universidade Católica do Rio de Janeiro (PUC-Rio), Ciências Biológicas, Rua Marquês de São Vicente, 225, Prédio Pe. Leonel Franca, 7 andar, CEP 22451-900, Rio de Janeiro, RJ, Brazil. ${ }^{3}$ Universidade Vila Velha-ES (UW), Rua Comissário José Dantas de Melo, 21, CEP: 29.102-770, Vila Velha, ES, Brazil.}

\section{Received: 14 July 2012 Accepted: 19 September 2012}

\section{Published: 28 September 2012}

\section{References}

Aguilar S, Condit R (2001) Use of native tree species by an hispanic community in Panama. Econ Bot 55(2):223-235

Albuquerque UP (1999) La importancia de los estudios etnobiológicos para establecimiento de estrategias de manejo y conservación en las florestas tropicales. Biotemas 12(1):31-47

Albuquerque UP, Araújo TAS, Ramos MA et al (2009) How ethnobotany can aid biodiversity conservation: reflections on investigations in the semi-arid region of NE Brazil. Biodivers Conserv 18:127-150

Alexiades MN, Sheldon JW (eds) (1996) Selected guidelines for ethnobotanical research: a field manual. The New York Botanical Garden Press, New York

Bremer B, Bremer K, Chase MW, Fay MF, Reveal JL, Soltis DE, Soltis PS, Stevens PF (2009) An update of the Angiosperm Phylogeny Group classification for the orders and families of flowering plants: APG III. Bot J Linn Soc 161:105-121

Calderon Al, Angerhofer CK, Pezzuto JM et al (2000) Forest plot as a tool to demonstrate the pharmaceutical potential of plants in a tropical forest of Panama. Econ Bot 54(3):278-294
Castelletti JCHM, Silva JMC, Tabarelli M et al (2003) Quanto ainda resta da Caatinga? Uma estimativa preliminar. In: Silva JMC, Tabarelli M, Fonseca MT (eds) (orgs) Biodiversidade da Caatinga: áreas e ações prioritárias para a conservação. Ministério do Meio Ambiente: Universidade Federal de Pernambuco, Brasília, pp 92-100

Chalmers N, Fabricius C (2007) Expert and generalist local knowledge about land-cover change on South Africa's Wild Coast: can local ecological knowledge add value to science? Ecol Soc 12(1):10

Chazdon RL, Coe FG (1999) Ethnobotany of woody species in second-growth, old-groth, and selectively logged forest of Northeastern Costa Rica. Conserv Biol 13(6):1312-1322

Christo AG, Guedes-Bruni RR, Fonseca-Kruel VS (2006) Uso de recursos vegetais em comunidades rurais limítrofes à Reserva Biológica de Poço das Antas, Silva Jardim, Rio de Janeiro: estudo de caso na Gleba Aldeia Velha. Rodriguesia 57(3):519-542

Christo AG, Guedes-Bruni RR, Sobrinho FAP et al (2009) Structure of the shrub-arboreal component of an Atlantic Forest fragment on a hillock on the central lowland of Rio de Janeiro, Brazil. Interciencia 34(4):232-239

Cundill GNR, Fabricius C, Marti N (2005) Foghorns to the future: using knowledge and transdisciplinarity to navigate complex systems. Ecol Soc 10(2):8

Cunha LVFC, Albuquerque UP (2006) Quantitative ethnobotany in na Atlantic Forest Fragment of Northeastern Brazil - implications to conservation. Environ Monit Assess 114:1-25

Dean W (1996) A ferro e fogo: a história e a devastação da Mata Atlântica Brasileira. Companhia das Letras, São Paulo

Donovan D, Puri R (2004) Learning from traditional knowledge of non-timber forest products: Penan Benalui and the autecology of Aquilaria in Indonesian Borneo. Ecol Soc 9(3):3

Fundação SOS Mata Atlântica (2009) Atlas dos Remanescentes Florestais da Mata Atlântica período 2005 - 2008 Relatório parcial. http://mapas.sosma.org.br/ site_media/download/atlas\%20mata\%20atlantica-relatorio2005-2008.pdf. Cited 13 sept 2009

Lawrence WF (2010) Beyond island biogeography theory understanding habitat fragmentation in the real world. In: Losos JB, Ricklefs RE (eds) The Theory of Island Biogeography Revisited. Princeton University Press, Princeton, pp 214-236

Galeano G (2000) Forest use at the Pacific Coast of Chocó, Colombia: a quantitative approach. Econ Bot 54(3):358-376

Gross T, Johnston S, Barber CV (2005) A Convenção sobre Diversidade Biológica: entendendo e influenciando o processo. Instituto de Estudos Avançados das Nações Unidas. Ministério do Meio Ambiente, Brasília

Guedes-Bruni RR, Quinet A, Barros CF et al (2000) 500 Anos de Mata Atlântica. Instituto de Pesquisas Jardim Botânico do Rio de Janeiro, Rio de Janeiro, CD-ROM

Guedes-Bruni RR, Silva AG, Mantovani W (2009) Rare canopy species in communities within the Atlantic Coastal Forest in Rio de Janeiro State, Brazil. Biodivers Conserv 18:387-403

Larrère R, Lepart J, Marty J et al (2003) École thematique du CNRS: Biodiversité: quelles interactions entre sciences de la vie et sciences de l'homme et de la société? Natures Sciences Sociétés 11:304-314

Lima HC, Pessoa SVA, Guedes-Bruni RR et al (2006) Caracterização fisionômicoflorística e mapeamento da vegetação da Reserva Biológica de Poço das Antas, Silva Jardim, Rio de Janeiro, Brasil. Rodriguesia 57(3):369-389

Mittermeier RA, Fonseca GAB, Rylands AB et al (2005) A brief history of biodiversity conservation in Brazil. Conserv Biol 19:601-607

Moerman DE (1996) An analysis of the food plants and drug plants of native North America. J Ethnopharmacol 52:1-22

Phillips OL, Gentry AH (1993a) The useful plants of Tambopata, Peru: I. Statistical hypotheses tests with a new quantitative technique. Econ Bot 47(1):15-32

Phillips OL, Gentry AH (1993b) The useful plants of Tambopata, Peru: II. Additional hypotheses testing in quantitative ethnobotany. Econ Bot 47(1):33-43

Phillips OL, Gentry AH, Reynel C et al (1994) Quantitative ethnobotany and amazonian conservation. Conserv Biol 8(1):225-248

Piñedo-Vásquez M, Zarín D, Jipp P et al (1990) Use-Values of tree species in a communal forest reserve in Northeast Peru. Conserv Biol 4(4):405-416

Prance GT, Boom BM, Baleé W et al (1987) Quantitative ethnobotany and the case for conservation in Amazonia. Conserv Biol 1(4):296-310

Soler-Alarcón JG, Peixoto AL (2008) Use of terra firme forest by Caicubi caboclos, middle Rio Negro, Amazonas, Brazil: a quantitative study. Econ Bot 62(1):60-73 
Torre-Cuadros MA, Islebe GA (2003) Traditional ecological knowledge and use of vegetation in southeastern México: a case study from Solferino, Quintana Roo. Biodivers Conserv 12:2455-2476

Veloso HP, Rangel-Filho ALR, Lima JCA (1991) Classificação da vegetação brasileira adaptada a um sistema universal. IBGE, Rio de Janeiro

doi:10.1186/2193-1801-1-21

Cite this article as: Christo et al.: Evidence for conservation and

sustainable use in a fragment of the Atlantic forest in southeastern Brazil by a traditional human group. SpringerPlus 2012 1:21.

Submit your manuscript to a SpringerOpen ${ }^{\circ}$ journal and benefit from:

- Convenient online submission

- Rigorous peer review

- Immediate publication on acceptance

- Open access: articles freely available online

- High visibility within the field

- Retaining the copyright to your article

Submit your next manuscript at $\gg$ springeropen.com 